\title{
Mechanism of Colloidal Attachment on Textile Fibrous Media
} Mehanizem koloidnega pritrjevanja na tekstilne vlaknaste medije

\author{
Scientific Review/Pregledni znanstveni članek \\ Received/Prispelo 03-2018 • Accepted/Sprejeto 03-2019
}

\begin{abstract}
Filtration through the porous media of a granular bed is one of the oldest and most favourable particle separation techniques used universally for the treatment of water. In the case of filtration through a granular bed, all physical factors are incorporated into a single collector contact efficiency. The latter is the ratio of the rate at which particles strike the collector to the rate at which particles flow towards the collector. On the other hand, collision or attachment efficiency represents the chemical interaction between the media used and colloids, and is expressed as the ratio of the number of particles removed by the collector to the number of particle collector collisions, or the possibility that a collision in an attachment. Textile media is emerging as a substrate in deep bed filtration due to its superior performance in the removal of colloidal particles from water under higher filtration velocities compared with granular media. Reported studies relating to the effect of physicochemical factors on colloidal removal in textile fibrous media are mainly based on the experimental value of the concentration variation of colloidal particles in input and output water. Presented in this paper is a way in which colloidal filtration theory can be extended to textile filter media in order to explain the mechanism of attachment of colloids (primarily bacteria) on a textile fibrous media surface.

Keywords: textile filter, single collector contact efficiency, collision efficiency, hydrophobicity, pore size, surface charge

\section{Povzetek}

Filtracija skozi porozni medij z zrnatim slojem je ena najstarejših in najboljših tehnik ločevanja delcev, ki se uporabljajo za obdelavo vode. Pri filtraciji skozi zrnati sloj so vsi fizikalni dejavniki vključeni v učinkovitost stika z enojnim filtracijskim medijem. Ta pomeni razmerje med hitrostjo, s katero se delci nabirajo na filtracijskem mediju, in hitrostjo, s katero se delci pomikajo proti filtracijskemu mediju. Po drugi strani pa je trk oziroma učinek pritrditve kemična interakcija med uporabljenim medijem in koloidi, izražena kot razmerje med številom delcev, ki jih je medij odstranil, in številom trkov ob filtracijski medij oziroma možnostjo za takšen trk. Tekstilni medij se manifestira kot nosilec filtracijskega globinskega sloja zaradi svojih odličnih zmogljivosti pri odstranjevanju koloidnih delcev iz vode pri višjih hitrostih filtracije v primerjavi z zrnatimi mediji. Študije, ki se nanašajo na učinek fizikalno-kemijskih dejavnikov na odstranitev koloidnih delcev v tekstilnih vlaknatih medijih, temelijo predvsem na eksperimentalni vrednosti variiranja koncentracije koloidnih delcev v vstopni in izstopni vodi. V prispevku je predstavljen način, kako lahko teorijo koloidne filtracije razširimo na tekstilne filtrne medije, da pojasnimo mehanizem pritrditve koloidov (predvsem bakterij) na tekstilno vlaknato površino. Ključne besede: tekstilni filter, učinkovitost stika z enojnim filtracijskim medijem, učinkovitost trka, hidrofobnost, velikost por, površinski nabo
\end{abstract}

\section{Introduction}

Colloids are finely divided particles distributed in a dispersion medium. The diameter of particles ranges from around $10 \mathrm{~nm}$ to $10 \mu \mathrm{m}[1]$. Many of these

Corresponding author/Korespondenčni avtor: Sukumar Roy

E-mail: sukumar.textile@gmail.com colloids (viruses, bacteria and protozoan parasites) in surface water pose a risk to public health [2]. $\mathrm{Nu}$ merous processes are available for the removal of these colloids, which is achieved using an attachment mechanism. Filtration through porous media 
is an effective process for the removal of colloids from surface water using an attachment mechanism [3]. Significant efforts have been made by a number of researchers in the development of colloidal filtration theory (mainly sand, glass bed, etc., as mentioned in theory) based on the physicochemical interaction between colloids and media [4-6]. The main limitations in granular media are the capacity to retain colloidal particles within the pore spaces and a low filtration rate [7]. However, granular filtration theory is well developed based on the physicochemical interaction of the bed and colloidal particles. Textile materials have emerged in recent years as a substrate that can be used as filter media for the removal of colloidal particles from surface water using an attachment mechanism [8]. Superior performance in the removal of colloidal particles from water can be achieved by textile fibrous media under filtration velocities that are ten times higher than granular media [9].

There are several varieties of textile fibre available on the market that can be used as filter media. However, the efficient removal of colloidal particles from surface water using a textile filter relies heavily on the type of fibres used as filtering media. Most textile filtration research is based on the effect of the shape, size, thickness, hydrophobicity and surface charge of textile media on filtration efficiency [10]. These factors of textile fibrous media filters are similar to the physicochemical factors of granular media that serve as the basis of an attachment mechanism. A quantitative analysis of textile fibrous media may be possible by extending the physicochemical interaction concept of granular media. The physicochemical factors of textile materials, such as shape, size, surface charge, the hydrophobicity of fibres, and media thickness and colloidal properties, determine the strength of colloidal-fibrous media physicochemical interactions [11]. Presented in this paper is a potential way to extend colloidal filtration theory to textile fibrous media in order to explain the mechanism of attachment of colloids (bacteria) on a textile media surface.

\subsection{Filtration theory}

Bacteria attachment in porous media as predicted by colloid filtration theory provides a model for determining the physical and chemical factors of particle retention in porous media. Physical controls over bacteria attachment in porous media depend on the geometry of the porous media, as well as bacteria.
The number of potential contacts of particles with a surface can be estimated based on a physical mechanism. This, in turn, facilitates the determination of the attachment of particles in porous media, which depends on the chemical forces affecting adhesion and repulsion [12].

Particle removal in a packed bed in a constant state using an attachment mechanism can be described using one-dimensional filtration equation 1 [13].

$\frac{d C}{d L}=-\frac{3}{2} \frac{(1-f)}{d_{c}} \eta C$

where $C$ is particle concentration (in number of bacterial per unit volume), $L$ is the thickness of the filter bed, $(1-f)$ is the solid fraction, $\eta$ is the single collector contact efficiency and $d_{c}$ is the collector diameter. Integration of the thickness of the packed bed yield is given in basic filtration equation 2 .

$F_{p}=\frac{C}{C_{0}}=\exp \left(\frac{3(1-f)}{2 d_{c}} L \eta\right)$

Where $F_{p}$ is fractional penetration and this is an indicator of the balance between cell adsorption and desorption.

Physical factors that account for particle collisions with porous media are incorporated into the single collector contact efficiency $(\eta)$. The single collector contact efficiency of a single media particle or collector $(\eta)$ is a ratio, i.e. the rate at which particles strike the collector to the rate at which particles flow towards the collector.

Numerous analytical solutions have been used to specify the single collector contact efficiency for filtration through granular media. Primarily transport mechanisms are used to develop the model for the theoretical calculation of single collector contact efficiency.

The Yao model, represented by equations $3-5$ describing deep bed filtration for liquid filtration, were proposed by Logan et al. [14]. Single collector contact efficiencies for this model are based on spherical collectors.

$\eta_{D}=4 P e^{-2 / 3}$

$\eta_{I}=\frac{3}{2} R^{2}$

$\eta_{G}=G$

Here, $\eta_{D}, \eta_{I}$ and $\eta_{G}$ represent theoretical values for the single collector contact efficiency when the sole 
transport mechanisms are diffusion, interception, or sedimentation, respectively. Single collector contact efficiency calculated numerically can be approximated by the sum of analytical equation 6 . In other words:

$\eta_{0}=\eta_{D}+\eta_{I}+\eta_{G}$

Single collector contact efficiencies are a dimensionless number and are developed from correlations using equations $7-9$.

$P e=\frac{U_{0} d_{c}}{D}$

$R=\frac{d_{p}}{d_{c}}$

$G=\frac{U_{p}}{U_{0}}$

Where $P_{e}$ is the peclet number, $R$ and $G$ are interception and gravitational numbers, $U_{0}$ and $U_{p}$ are filter super facial velocity $(L / T)$ and particle settling velocity $(L / T), D$ is particle diffusivity $\left(L^{2} / T\right), d_{p}$ is the particles diameter and $d_{c}$ is the collector diameter. The particle settling velocity is obtained using equation 10.

$U_{p}=\frac{g\left(p_{p}-p_{f}\right) d_{p}^{2}}{18 \vartheta p_{f}}$

$\mu$ and $\vartheta$, dynamic and kinematic viscosity $\left(M L^{-1} T^{-1}\right)$ of fluid $g$ is the gravitational constant $(L / T)$, where $p_{p}$ and $p_{f}$ the particle and fluid density $\left(M / L^{3}\right)$. The particle diffusivity is obtained using the Stokes-Einstein equation (equation 11).

$D=\frac{k T}{3 \pi \mu d_{p}}$

where $k\left(M L^{2} T^{-2} K^{-1}\right)$ is Boltzmann's constant and $T(\mathrm{~K})$ is the absolute temperature.

The quantitative assessment of bacterial attachment to a collector surface is carried out by determining the collision efficiency (attachment) factor $(\alpha)$, and is often expressed as the ratio of experimental single collector efficiency $(\eta)$, calculated using equation 2 , to the predicted single collector efficiency $\left(\eta_{o}\right)$, calculated using equation 6 , or the possibility that a collision in an attachment, which is obtained using equation 12.

$\alpha=\frac{\eta}{\eta_{0}}$

\section{Physicochemical factors of textile fibrous media affecting the removal of colloidal particles}

\subsection{Fibre size/diameter}

In textile porous media, the attachment of colloids on the surface of a fibre is influenced by the fibre diameter. It has been reported that a lower fibre diameter will result in the higher removal efficiency of colloids due to the high specific surface area and good interconnectivity of pores [15]. The mean pore size of a fibrous media is highly dependent on the fibre diameter [16]. Eichhorn and Sampson used a theoretical model to demonstrate that the fibre diameter plays an important role in controlling the pore size of an electrospun nanofibrous network used for water filtration [17]. Zhou et al. [18] studied the removal of colloidal particles in cellulose acetate nanofibers membranes at different fibre diameters. They found that membranes with a lower fibre diameter had a higher removal efficiency than membranes with a higher fibre diameter. Desai et al. [19] studied the bacteria removal efficiency of nanofibers filter media by varying the diameter of the fibre. They reported that an increase in fibre diameter resulted in a decrease in filtration efficiency. It has been reported that the fibre diameter in textile filter media plays an important role in improving filtration efficiency.

\subsection{Fibre shape/cross section}

Many studies have been carried out on the effect of the shape of the fibre in textile media on colloidal removal in the filtration process. A higher projected surface area resulting from a different cross-section facilitates the probability of capturing colloids particles. Recently, hollow nanofiber membranes have emerged as substrates for use in liquid filtration [20]. Wang et al. [21] found that hollow fibre membranes have excellent intrinsic separation properties due to their highly porous and narrow pore size distribution, which leads to high filtration efficiency. Fibre cross-section could also be considered an important factor in colloidal filtration in textile filter media.

\subsection{Fibre media thickness}

The thickness of the media also affects the removal efficiency of a filter. Kaur et al. [22] suggested that if a fibrous media is used to separate sub-microns 
particles, a thicker fibrous layer is required to reduce the overall average pore size of the media. A higher media thickness is associated with increased colloidal removal due to the overlapping of the fibres in the media, resulting in fine sized pores, which facilitates the trapping of particles [18]. It has also been reported that the removal of clay particles increases with an increase in the thickness of the polypropylene fibrous barrier. It was claimed that a thicker barrier should provide more chances for the interception of clay particles [23-25].

\subsection{Fibre hydrophobicity}

The hydrophobicity of textile fibres is considered an important chemical factor that affects colloidal removal in textile fibrous media. Most colloidal particles are hydrophobic in nature. Hydrophobic interaction plays an important role in the efficient removal of colloidal particles [26]. The kinetics of the capture of colloidal particles is also determined by the magnitude of the hydrophobic interaction between particles and collectors. Hydrophobic interaction increases with an increase in the hydrophobicity of the filter media. The hydrophobicity of the media is characterised in terms of contact angle value [11]. Arnold et al. [27] reported that hydrophobicity is directly proportional to the contact angle of water with its surface and inversely proportional to the work of adhesion. Fletcher et al. [28] found a strong positive correlation between the number of bacteria attached to the surface and the

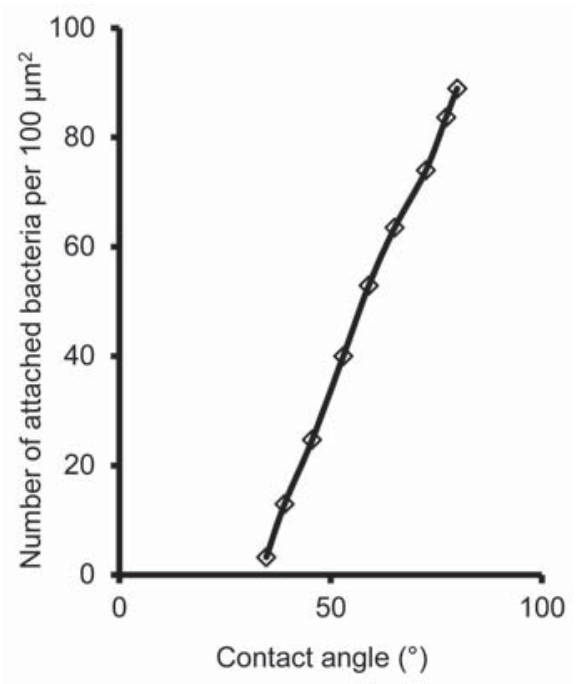

Figure 1: Relationship between bacteria attachment and the water contact angle on materials [28] hydrophobic nature of polymers, as determined by the contact angle. It is evident in Figure 1 that an increase in the contact angle results in increased bacteria attachment. Pringle et al. [29] calculated a lower work of adhesion for nylon $\left(98 \mathrm{~mJ} / \mathrm{m}^{2}\right)$ than for glass $\left(146 \mathrm{~mJ} / \mathrm{m}^{2}\right)$. In an experiment with two pseudomonas species, it was observed that the attachment of these cells was higher to the nylon fibres than to the borosilicate glass surface because of the higher hydrophobicity of the nylon fibre.

\subsection{Fibre surface charge}

The removal of colloidal particles using relatively wide pore size fibrous media can be influenced not only by sieving parameters (pore size and pore size distribution) but also by the chemical interaction taking place between the colloidal particles and fibrous media [30, 31]. Cookson et al. [32] reported that attachment is brought about by the colloid-media chemical interaction controlled by the surface properties of the respective materials. Surface charge is one of the most important surface properties controlling the effective attachment of colloids on the fibre surface in textile fibrous media. It was reported that a possible mechanism for the removal of smaller-sized colloidal particles could be the electrostatic attraction between the opposite charges of the fibres and the particles, which causes the deposition of particles on the fibre surface [33-35]. The fibre surface charge is characterised in terms of zeta potential. It is measured using a streaming potential method on the surface of the fibres. The surface charges of fibres are the result of the disassociation of fibre surface groups in an aqueous medium. The isoelectric point (IEP) is the $\mathrm{pH}$ value corresponding to zero zeta potential and is different from fibre to fibre, depending on the surface properties [36]. Kang et al. [33] studied the adsorption of negatively charged nanoparticles on cationic, surfactanttreated microporous polypropylene filters. They reported that filtration efficiency can be increased from $10 \%$ to $90 \%$ through this surface modification. This can be attributed to the lowering energy barrier between the particles and filter media. Druet et al. [37] investigated the removal efficiency of heavy metal using positively charged, chitosan-treated polyethylene terephthalate geotextiles. They claimed that the higher positive charge of the media at an acidic $\mathrm{pH}$ will result in higher metal removal efficiency. In the desalination process based on textile nanofibers membranes, most membranes are characterised by a negative surface 


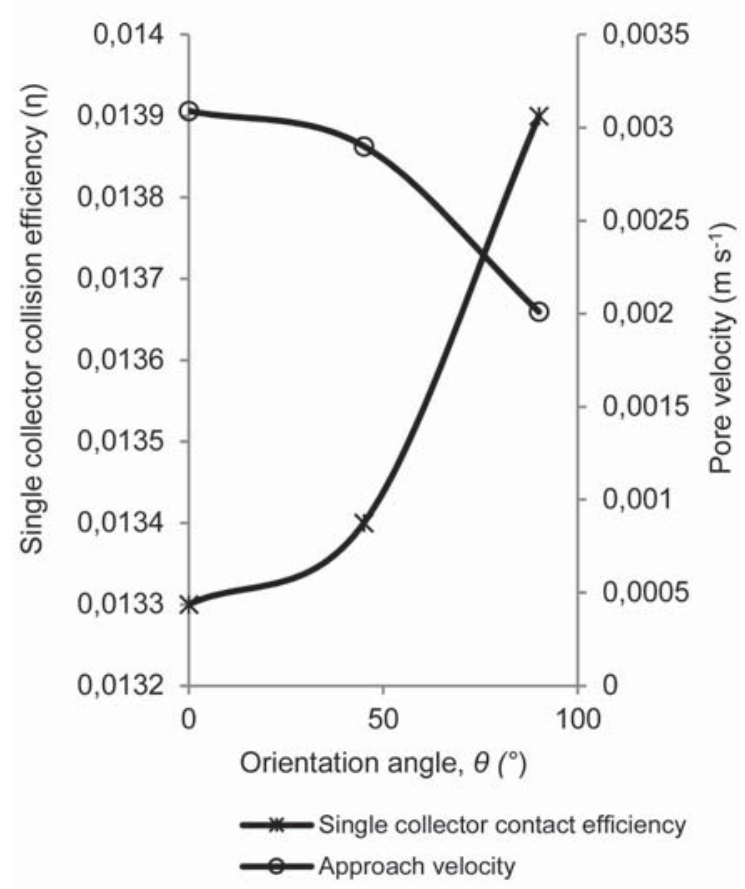

Figure 4: Effect of fibre orientation on single collector contact efficiency and approach velocity [42]

To quantitatively compare removal efficiency with different fibre orientations under identical solution conditions, the value of collision (attachment) efficiency $(\alpha)$ is calculated using equation no. 12, which is used in colloidal filtration theory. It has been reported that a high fibre orientation angle may lead to the exposure of a greater surface area for the striking

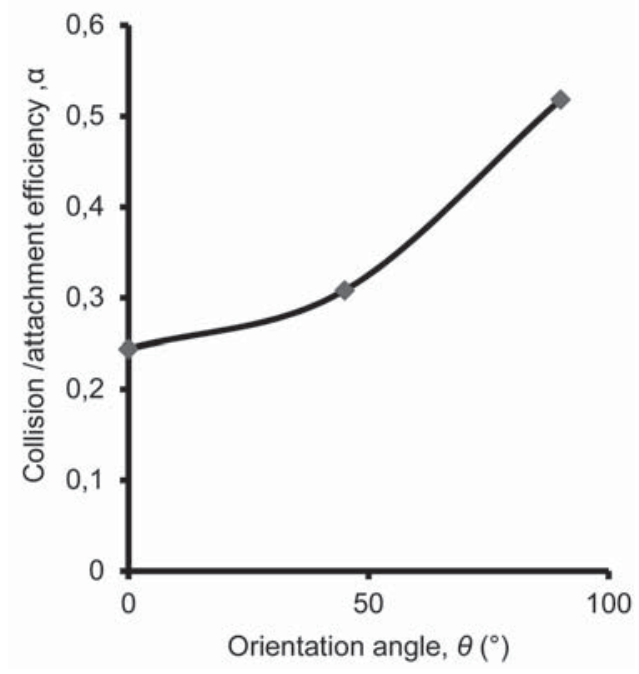

Figure 5: Collision efficiency as a function of the orientation angle [42] of bacteria, resulting in high collision efficiency. A higher collision efficiency means higher bacteria attachment, where its maximum value is 1 . It is evident from Figure 5 that an increase in fibre orientation results in an increase in collision efficiency.

\subsection{Effect of fibre mass on bacteria removal efficiency}

In another study conducted by Roy et al [43] on the effect of fibre mass on bacterial attachment, it was determined that removal efficiency increases with an increase in media mass up to a certain level (Figure 6). This is due to the change in single collector

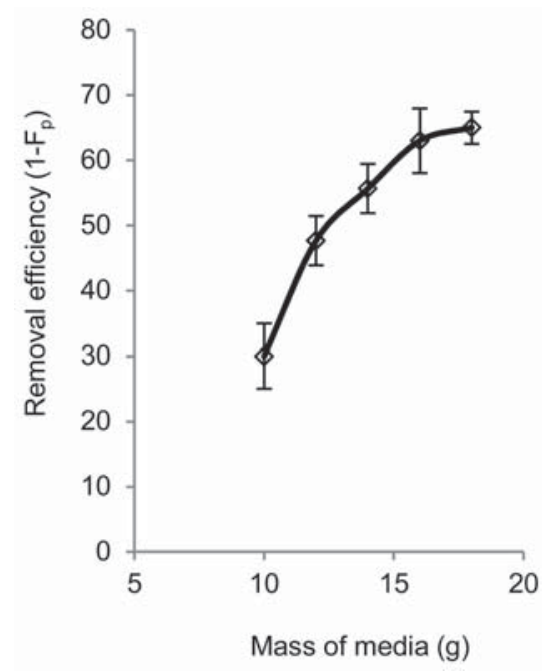

Figure 6: Removal efficiency as a function of media mass [43]

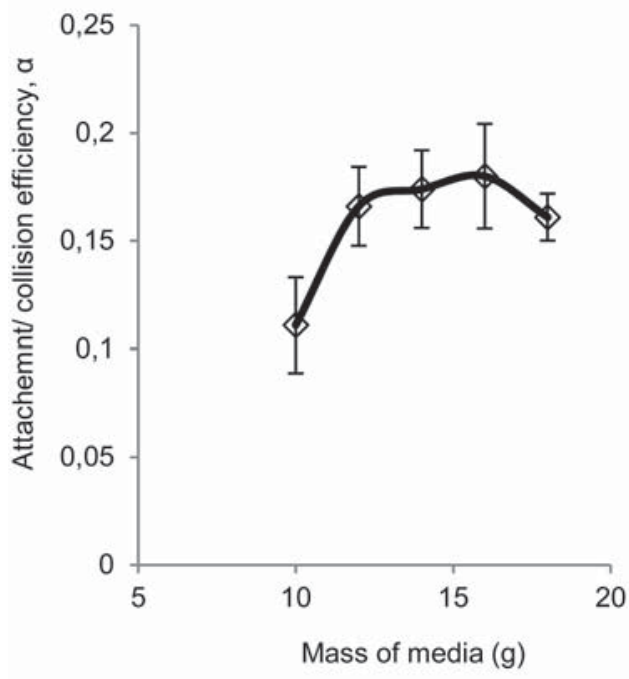

Figure 7: Collision efficiency as a function of media mass [43] 
charge to enhance the removal of dissolved salts [38, 39]. Berg et al. [40] found that the electrostatic repulsion force of negatively charged pesticides on the surface of a negatively charged membrane is expected to enhance the overall removal efficiency.

Based on the above literature, it can be concluded that the physicochemical factors of textile fibrous media are identified on the basis of filtration efficiency, which is expressed in terms of the concentration variation of colloidal particles in input and output water. The effect of physicochemical factors on the mechanism of attachment of colloidal particles, primarily bacteria on textile fibrous media, may also be systematically investigated by using colloidal filtration theory.

\section{Selected approaches to the application of colloidal filtration theory for textile material}

An attempt has been made by a few researchers to use colloidal filtration theory to explain colloidal removal by an attachment mechanism in textile porous media. Dagaonkar et al. [41] used DLVO theory to explore the effect of solution chemistry on colloidal removal in nonwoven polyester filter fabric.

They reported that under unfavourable attachment conditions using bivalent salt $\left(\mathrm{CaCl}_{2}\right)$, removal efficiency increased from $35 \%$ to $62 \%$ compared to monovalent salt $(\mathrm{NaCl})$, while the removal efficiency remain constant at around $38 \%$ for the ionic strength range of 0 to $100 \mathrm{mM}$ (Figure 2).

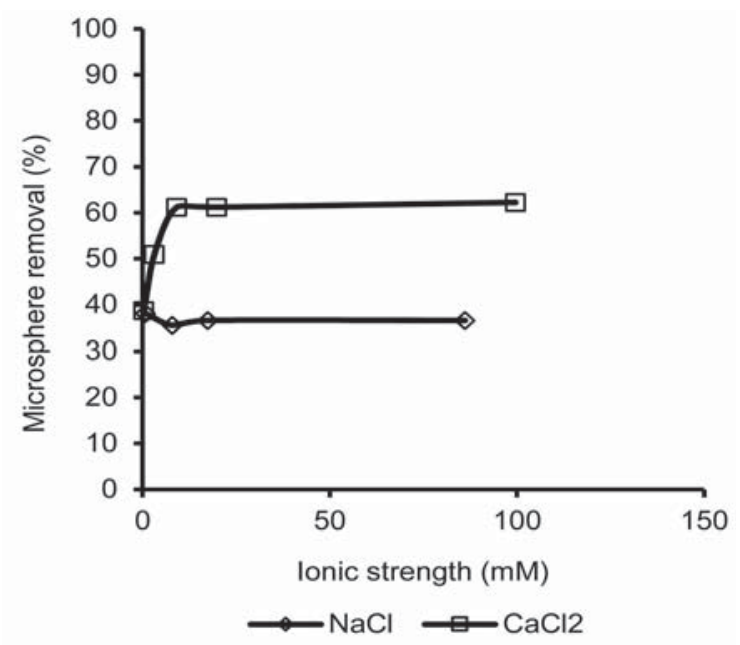

Figure 2: Microsphere removal as a function of ionic strength using different types of salts [41]

\subsection{Effect of fibre orientation on bacteria filtration}

Roy et al [42] investigated the attachment of bacteria to fibrous material as a function of fibre orientation to the direction of the liquid flow. Removal trends were explained on the basis of colloidal filtration theory. They reported that by changing fibre orientation from $0^{\circ}$ to $90^{\circ}$, bacteria removal efficiency increased from $30 \%$ to $54.54 \%$, suggesting that the attachment of bacteria on the media surface depends on fibre orientation (Figure 3)

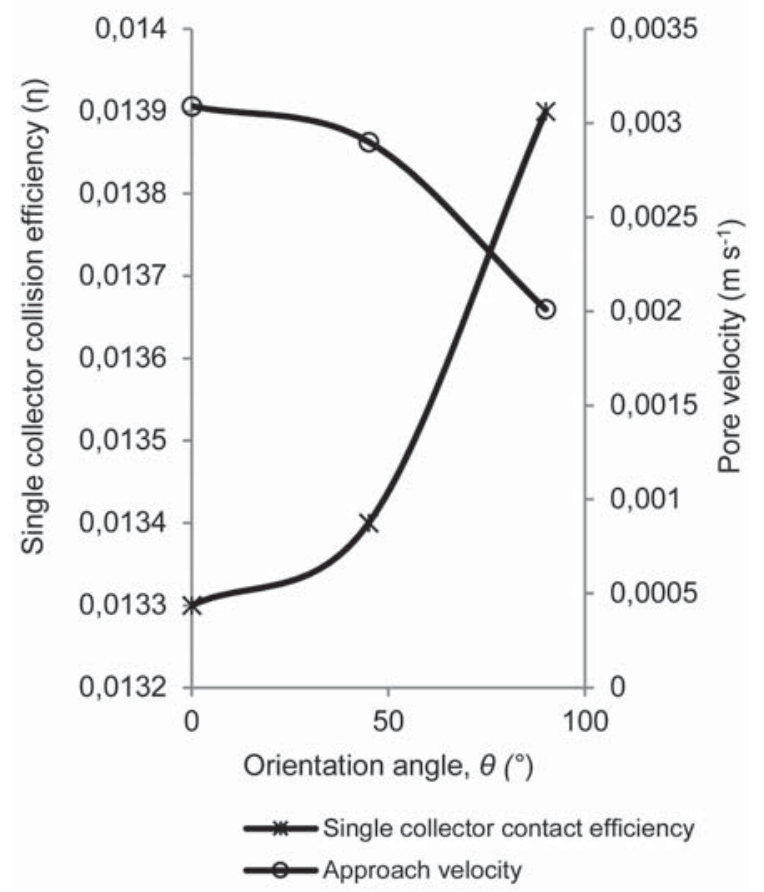

Figure 3: Removal efficiency as a function of the fibre orientation angle [42]

It is evident from Figure 4 that single collector efficiency increases from $1.33 \times 10^{-2}$ to $1.39 \times 10^{-2}$ by changing fibre orientation from $0^{\circ}$ to $90^{\circ}$. This is due to a decrement in the approach velocity of the filtration system from $3.09 \times 10^{-3}$ to $2.01 \times 10^{-3} \mathrm{~m} / \mathrm{s}$. Enhanced single collector contact efficiency by increasing fibre orientation has therefore been attributed to a change in the approach velocity of water in the filtration system. A potential explanation is that a high fibre orientation angle may lead to the exposure of a greater surface area for the striking of bacteria, resulting in high collector contact efficiency. 
contact efficiency and attachment/collision efficien$c y$, as observed from experimental data regarding removal efficiency.

It is evident from Figure 7 that changing the media mass increases and then decreases collision efficiency $(\alpha)$.

\subsection{Effect of different fibrous material on bacterial attachment}

Many researches have studied the effect of different media material on bacterial attachment in textile fibrous media. Roy et al. [44] reported that nylon

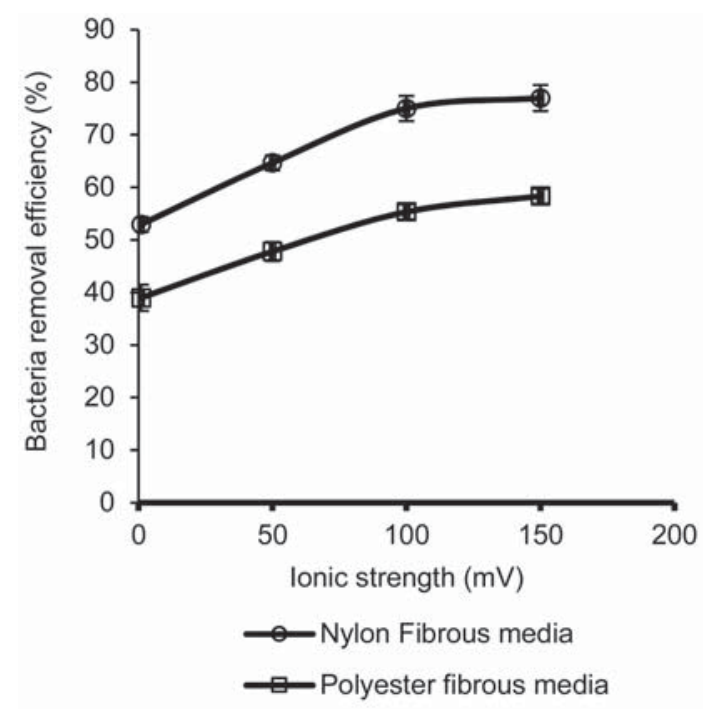

Figure 8: Effect of ionic strength on bacteria removal in different fibrous media [44]

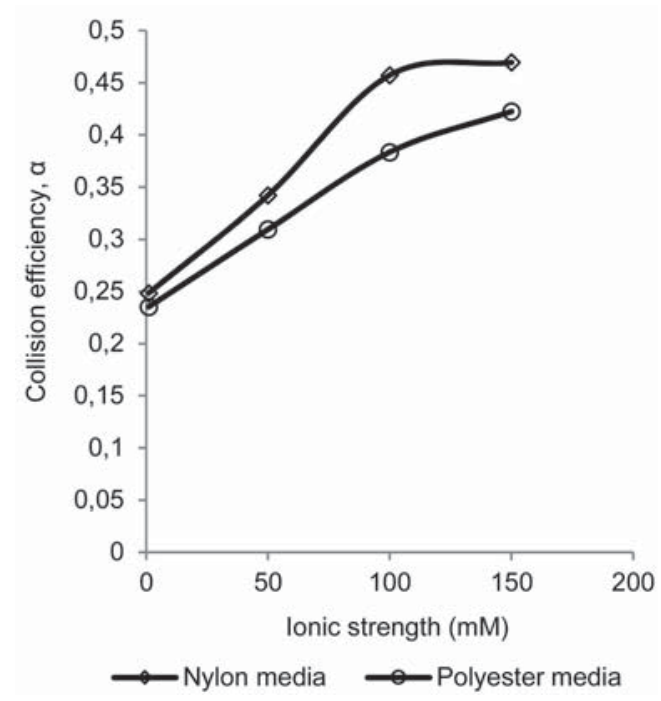

Figure 9: Collision efficiency as a function of ionic strength for different media material [44] fibrous media demonstrates a higher removal efficiency than polyester fibrous media for the same solution chemistry (Figure 8). The bacteria removal efficiency of nylon and polyester fibrous filter media are explained based on colloidal filtration theory.

The removal and attachment of bacteria on a fibrous surface thus increases with an increase in ionic strength, which can be attributed to a change in collision efficiency. It is evident from Figure 9 that the change in collision efficiency is higher for nylon than for polyester, resulting in a higher removal efficiency by nylon fibrous media.

\section{Conclusion}

The reported study demonstrated that the fibre orientation of the filter media may play an important role in bacterial attachment. Bacteria attachment and removal efficiency increase with an increase in the fibre orientation angle. According to colloidal filtration theory, this is possible due to a change in the collision (attachment) efficiency of the fibrous media. Bacteria attachment and removal efficiency increase with an increase in media mass up to a certain level. It is also evident from reported studies that media materials play an important role in bacterial attachment in a fibrous packed bed.

The higher bacteria removal efficiency of nylon fibrous media than polyester fibrous media is due to the higher collision efficiency of nylon fibre $(0.24$ to $0.46)$ than polyester fibre $(0.23$ to 0.42$)$ at the ionic strength range of $1 \mathrm{mM}$ to $150 \mathrm{mM}$.

Hence, the concept of dimensionless a (attachment efficiency) or $\eta$ (single collector contact efficiency) of a granular media filter can be extended to textile filter media for the purpose of explaining the mechanism of attachment of colloids (bacteria) on textile fibrous media.

\section{References}

1. DENOVIO, Nicole M., SAIERS, James E., RYAN, Joseph N. Colloid movement in unsaturated porous media: recent advances and future directions. Vadose Zone Journal, 2004, 3(2), 338-351, doi: 10.2113/3.2.338. 
2. MCCARTHY, John E., ZACHARA, M. John. Subsurface transport of contaminants. Environmental Science and Technology, 1989, 23, 469502, doi: 10.1021/es00063a001.

3. GITIS, Vitaly, RUBINSTEIN, Isaak, LIVSHITS, Maya, ZISKIND, Gennady. Deep-bed filtration model with multistage deposition kinetics. Chemical Engineering Journal, 2010, 163(1-2), doi: $10.1016 /$ cej.2010.07.044.

4. DAI, Xiaojun, HOZALSKI, Raymond M. Evaluation of microspheres as surrogates for cryptosporidium parvum oocysts in filtration experiments. Environmental Science \& Technology, 2003, 37(5), 1037-1042, doi: 10.1021/es025521w.

5. DAI, Xiaojun, HOZALSKI, Raymond. Effect of NOM and biofilm on the removal of Cryptosporidium parvum oocysts in rapid filters. Water Research, 2002, 36, 3523-3532, doi: 10.1016/ S0043-1354(02)00045-3.

6. ELIMELECH, Menachem. Spatial distributions of Cryptosporidium oocysts in porous media: evidence for dual mode deposition. Environmental Science \& Technology, 2005, 39(10), 3620-3629, doi: 10.1021/es048289y.

7. BOLLER, Marcus, KAVANAUGH, M. C. Particle characteristics and headloss increases in granular media filtration. Water Research, 1995, 29, 1139-1149, doi: 10.1016/0043-1354(94)00256-7.

8. LEE, Jungjune, CHA, Jaehwan, AIM, Roger Ben, HAN, K. B., KIM, Chang-Gyun. Fiber filter as an alternative to the process of flocculation sedimentation for water treatment. Desalination, 2008, 231(1-3), 323-331, doi: 10.1016/j. desal. 2007.11.051.

9. LEE, Jungjune, JOHIR, Md Abu Hasan, CHINU, Khorshed, VIGNESWARAN, S., KANDASAMY, J., KIM, Chang-Gyun, SHAW, K. Novel pretreatment method for seawater reverse osmosis: Fibre media filtration. Desalination, 2010, 250(2), 557-561, doi: 10.1016/j.desal.2009.09.023.

10. WANG, Chiu-Sen. Electrostatic forces in fibrous filters - a review. Powder Technology, 2001, 118(1-2), 166-170, doi: 10.1016/S00325910(01)00307-2.

11. PLAKAS, Konstantinos V., KARABELAS, Anastasios J. Removal of pesticides from water by NF and RO membranes - A review. Desalination, 2012, 287, 255-265, doi: 10.1016/j. desal.2011.08.003.

12. ADAMS, T. Bacterial attachment in porous media. The University of Arizona, 1992.

13. YAO, Kuan-Mu, MOHAMMAD, T. Habibian, O'MELIA, Charles R. Water and waste water filtration: concept and applications. Environmental Science \& Technology, 1971, 5(11), 11051112, doi: 10.1021/es60058a005.
14. LOGAN, Bruce E., JEWETT, D. G., ARNOLD, R. G., BOUWER, E. J., O'MELLIA, Charles R. Clarification of clean-bed filtration model. Journal of environmental engineering, 1995, 121(12), 869-873, doi: 10.1061/(ASCE)0733-9372(1995) 121:12(869).

15. LI, Dapeng, FREY, Margaret, W., JOO, Yong L. Characterization of nanofibrous membranes with capillary flow porometry. Journal of Membrane Science, 2006, 286, 104-114, doi: 10.1016/j.memsci.2006.09.020.

16. RJU, Young Jun, KIM, Hak Yong, LEE, Keun Hyung, PARK, Heui Chon, LEE, Douk Rae. Transport properties of electrospun nylon 6 nonwoven mats. European Polymer Journal, 2003, 39, 1883-1889, doi: 10.1016/S0014-3057(03)00096-X.

17. HSIEH, Y. C., YANO, H., NOGI, M., EICHHORN, S. J. An estimation of the Young's modulus of bacterial cellulose filaments. Cellulose, 2008, 15, 507-513, doi: 10.1007/s10570-0089206-8.

18. ZHOU, Zhengping, LIN, Wei, WU, Xiang-Fa. Electrospinning ultrathin continuous cellulose acetate fibers for high-flux water filtration. Colloids and Surfaces A: Physicochemical and Engineering Aspects, 2016, 494, 21-29, doi: 10.1016/j. colsurfa.2015.11.074.

19. DESAI, Keyur, KIT, Kevin, LI, Jiajie, DAVIDSON, Michael, ZIVANOVIC, Svetlana, MEYER, Harry. Nanofibrous chitosan non-wovens for filtration applications. Polymer, 2009, 50(15), 3661-3669, doi: 10.1016/j.polymer.2009. 05.058 .

20. FENG, Chaoyang, KHULBE, Kailash, MATSUURA, T., TABE, Shahram, ISMAIL, Ahmad Fauzi. Preparation and characterization of electro-spun nanofiber membranes and their possible applications in water treatment. Separation and Purification Technology, 2013, 102, 118135, doi: 10.1016/j.seppur.2012.09.037.

21. WANG, Peng, TEOH, May May, CHUNG, TaiShung. Morphological architecture of dual-layer hollow fiber for membrane distillation with higher desalination performance. Water Research, 2011, 45(17), 5489-5500, doi: 10.1016/j. watres.2011.08.012.

22. KAUR, Satinderpal, GOPAL, Renuga, NG, Wun Jern, RAMAKRISHNA, Seeram, MATSUURA, Takeshi. Next-Generation fibrous media for water treatment. MRS Bulletin, 2008, 33(1), 21-26, doi: $10.1557 / \mathrm{mrs} 2008.10$.

23. YU, Jianghua, KIM, Youngchul. Performance evaluation and modeling of synthetic-fiber barrier in the treatment of turbid water. Water Environment Research, 2013, 85(7), 596-603, doi: $10.2175 / 106143013 X 13698672321427$. 
24. LIU, Li, XU, Zhonghou, SONG, Cunyi, GU, Qingbao, SANG, Yimin, LU, Guilan, HU, Hualong, LI, Fasheng. Adsorption-filtration characteristics of melt-blown polypropylene fiber in purification of reclaimed water. Desalination, 2006, 201(1-3), 198-206, doi: 10.1016/j. desal. 2006.02.014.

25. YU, Jianghua, YU, Haixia, KIM, Youngchul. Model development and application design of fiber mat used for turbid runoff treatment. Environmental Science and Technology, 2013, 34(11), 1429-1437, doi: 10.1080/09593330.2012.752873.

26. EDWARD, S. K. Chian, BRUCE, Willis N., FANG, H. P. Herbert. Removal of pesticides by reverse osmosis. Environmental Science \& Technology, 1975, 9(6), 52-59, doi: 10.1021/ es60099a009.

27. LOGAN, E. Bruce, HILBERT, A. Thomas, ARNOLD, G. Robert Removal of bacteria in laboratory filters: models and experiments. Water Research, 1993, 27(6), 955-962, doi: 10.1016/ 0043-1354(93)90059-Q.

28. FLETCHER, Madilyn, LOEB, G. I. Influence of substratum characteristics on the attachment of a marine pseudomonad to solid surfaces. Applied and environmental microbiology, 1979, 37(1), 67-72.

29. PRINGLE, James H., FLETCHER, Madilyn. Influence of substratum wettability on attachment of fresh- water bacteria to solid-surfaces. Applied and Environmental Microbiology, 1983, 45(3), 811-817.

30. BOUSSAHEL, Rachdi, BOULAND, S., MOUSSAOUI, K. M., MONTIEL, A. Removal of pesticide residues in water using the nanofiltration process. Desalination, 2000, 132(1-3), 205-209, doi: 10.1016/S0011-9164(00)00151-X.

31. BOUSSAHEL, Rachdi, MONTIEL, A., BAUDU, Michel. Effects of organic and inorganic matter on pesticide rejection by nanofiltration. Desalination, 2002, 145(1), 109-114, doi: 10.1016/ S0011-9164(02)00394-6.

32. COOKSON, John T. Jr. Removal of submicron particles in packed beds. Environmental Science \& Technology, 1970, 4(2), 128-134, doi: 10.1021/ es60037a005.

33. KANG, Peter K., SHAH, Dinesh O. Filtration of nanoparticles with dimethyldioctadecylammonium bromide treated microporous polypropylene filters. Langmuir, 1997, 13(6), 1820-1826, doi: 10.1021/la961010+.

34. YANG, Shinhao, LEE, Grace W. M., LUO, ChinSiang, WU, Chih-Cheng, YU, Kuo-Pin. Loading characteristics of filter pretreated with anionic surfactant for monodisperse solid particles. Powder Technology, 2005, 156(1), 52-60, doi: 10.1016/j.powtec.2005.06.005.
35. HINESTROZA, Juan P., KIM, Joyoun, JASPER, Warren J. Charge characterization of an electrically charged fiber via electrostatic force microscopy. Journal of Engineered Fibers and Fabrics, 2006, 1(2), 30-46, doi: 10.1177/ 15589250060010020.

36. DELGADO, Angel V., GONZÁLEZ-CABALLERO, Fernando, HUNTER, R. J., KOOPAL, Luuk K., LYKLEMA, J. Measurement and interpretation of electrokinetic phenomena. Pure and Applied Chemistry, 2005, 77(10), 1753-1805, doi: 10.1351/pac200577101753.

37. DRUET, Julie, EL ACHARI, Ahmida, ISAAD, Jalal. Efficient removal of heavy metals from aqueous solution by chitosan-coated geotextiles based on polyethylene terephthalate. Research on Chemical Intermediates, 2015, 41(11), 88558876, doi: 10.1007/s11164-015-1933-5.

38. XU, Yazhen, LEBRUN, Remi E. Investigation of the solute separation by charged nanofiltration membrane : effect of $\mathrm{pH}$, ionic strength and solute type. Journal of Membrane Science, 1999, 158(1-2), 93-104, doi: 10.1016/S0376-7388(99)00005-8.

39. DESHMUKH, Shivaji, CHILDRESS, Amy E. Zeta potential of commercial RO membranes : influence of source water type and chemistry. Desalination, 2001, 140(1), 87-95, doi: 10.1016/ S0011-9164(01)00357-5.

40. BERG, P., HAGMEYER, Georg, GIMBEL, R. Removal of pesticides and other micropollutants by nanofiltration. Desalination, 1997, 113(2-3), 205-208, doi: 10.1016/S0011-9164(97)00130-6.

41. DAGAONKAR, Manoj, MAJUMDAR, Udayan. Effect of fluid flow, solution chemistry and surface morphology of fibrous material on colloid filtration. Journal of Engineered Fibers and Fabrics, 2012, 7(3), 62-74, doi: 10.1177/ 155892501200700309.

42. ROY, Sukumar, GHOSH, Subrata, BHOWMICK, Niranjan. Application of colloidal filtration theory on textile fibrous media: effect of fiber orientation on bacterial removal efficiency and attachment. Journal of The Institution of Engineers (India): Series E, 2018, 99(1), doi: 10.1007/s40034-018-0120-9.

43. ROY, Sukumar, GHOSH, Subrata, BHOWMICK, Niranjan. Application of colloidal filtration theory to bacterial attachment in textile fibrous media. Tekstilec, 2018, 61(3), 171-178, doi: 10.14502/Tekstilec2018.61.171-178.

44. ROY, Sukumar, GHOSH, Subrata, BHOWMICK, Niranjan. Mechanism of bacterial attachment on textile fibrous media. The Journal of The Textile Institute, 2018, doi: 10.1080/ 00405000.2018.1533442. 